\title{
ANALISIS RASIO KEUANGAN UNTUK MENILAI KINERJA KEUANGAN PADA KOPERASI PEGAWAI REPUBLIK INDONESIA (KPRI) BAKTI GURU PALEMBANG
}

\author{
Oleh : Sakdia \\ (SMP KARTIKA II-1 PALEMBANG)
}

$\underline{\text { Sakdhia@gmail.com }}$

\begin{abstract}
Abstrak-Penelitian ini dibuat dengan tujuan untuk mengetahui, menghitung dan menganalisis kinerja keuangan pada Koperasi Pegawai Republik Indonesia (KPRI) Bakti Guru Palembang dari tahun 2016 sampai 2018. Dengan Menggunakan 4 standar rasio penilaian yang terdiri dari: Permodalan, Kualitas Aktiva Produktif, Efisiensi dan Likuiditas. Metode penelitian yang dipilih dan di pakai menggunakan kuantitatif deskriptif. Hasil penelitian di nyatakan bahwa kinerja keuangan pada KSP (Koperasi Simpan Pinjam) Bakti Guru Palembang. Pada tahun 2016 perolehan skor akhir dari penilaian ke 4 aspek tersebut yakni 57 point, sedangkan pada tahun 2017 total akhir yang di dapat yakni 60 point, selisi 3 point dari tahun 2016 yang artinya mengalami kenaikan di tahun 2017. Sedangkan di tahun 2018 kembali mengalami penurunan yang drastis yakni dengan point 51,5 penurunan ini di akibatkan perolehan skor pada spek likuiditas di bagian rasio kas dari 10 menjadi 2,5. Maka dapat disimpulkan bahwa kinerja keuangan pada Koperasi Simpan Pinjam Bakti Guru Palembang sepanjang 3 tahun terakhir ini, yakni dari tahun 2016 sampai dengan 2018, menunjukkan bahwa kinerja keuangan koperasi mengalami naik turun di setiap tahunnya.
\end{abstract}

Kata Kunci: Analisis Rasio Keuangan, Kinerja Keuangan, Koperasi Pegawai Republik Indonesia (KPRI) Bakti Guru

\begin{abstract}
This research was made with the aim to find out, calculate and analyze the financial performance of the Employee Cooperative of the Republic of Indonesia (KPRI) Bakti Guru Palembang from 2016 to 2018. By using 4 standard assessment ratios consisting of: Capital, Earning Asset Quality, Efficiency and Liquidity. The research method chosen and used uses descriptive quantitative. The results of the study stated that the financial performance of KSP (Cooperative Savings and Loans) Bakti Guru Palembang. In 2016 the final score obtained from the assessment of the 4 aspects is 57 points, while in 2017 the final total obtained is 60 points, 3 points of 2016 which means an increase in 2017. While in 2018 it has decreased again drastic namely with a point of 51.5 this decline is caused by the acquisition of scores on the liquidity spec in the cash ratio from 10 to 2.5. Then it can be concluded that the financial performance of the Palembang
\end{abstract}


Savings and Loans Cooperative for Bakti Guru for the past 3 years, namely from 2016 to 2018, shows that the financial performance of cooperative has fluctuated every year.

Keywords: Financial Ratio Analysis, Financial Performance, Employee Cooperatives of the Republic of Indonesia (KPRI) Bakti Guru

\section{PENDAHULUAN}

Menurut Rudianto (2010:3) "koperasi adalah sebagai perkumpulan orang yang secara sukarela mempersatukan diri untuk berjuang meningkatkan kesejahteraan ekonomi melalui pembentukan sebuah badan usaha yang dikelola secara demokratis". Koperasi merupakan salah satu badan usaha yang ada di Indonesia, koperasi dianggap mampu untuk mewujudkan kesejahteraan anggotanya khususnya masyarakat pada umumnya. Hal ini di tegaskan dalam tujuan koperasi itu sendiri.

$$
\text { Menurut UU No.25 Tahun }
$$

1992 "Koperasi bertujuan memajukan kesejahteraan anggota pada khususnya masyarakat pada umumnya serta ikut membangun tatanan perekonomian nasional dalam rangka mewujudkan masyarakat yang maju, adil, dan makmur berlandaskan pancasila dan UUD 1945". Koperasi salah satu bentuk organisasi yang mendapatkan perhatian khusus bagi pemerintah, pada umumnya koperasi masih di anggap sebagian orang suatu bentuk kesatuananggota yang memiliki ekonomi masih di atasmasih di atas rata-rata dengan tujuan untuk meningkatkan kesejahteraan anggotanya serta masyarakat pada umumnya. Akan tetapi dalam hal tersebut koperasi merupakan lembaga yang sangat dibutuhkan oleh masyarakat serta menjadi kegiatan usaha dan pelayanan yang sangatmembantu dan diperlukan oleh para anggota koperasi.

Menurut Rudianto (2010:5) "Dilihat dari bidang usaha dan jenis anggotanya, koperasi dapat dikelompokan dalam 4 jenis yaitu: Koperasi Simpan Pinjam, Koperasi Kosumen, Koperasi Pemasaran, dan Koperasi Produsen. Aktivitas pada koperasi sangat lah penting dalam meningkatkan usahanya, terutama di bagian keuangan hal ini harus di perhatikan karena bagian keuangan lah yang menjadi ujung tombak dalam peningkatan dan perkembangan koperasi". Seorang pimpinan koperasi harus dapat memahami kondisi keuangannya karena pada dasarnya kondisi keuangan tersebut akan mempengaruhi kelangsungan hidup koperasi secara keseluruhan.

Salah satu cara melihat sehat atau tidak suatu koperasi dinilai dari laporan keuangannya yaitu dengan menganalisa laporan keuangan. Hasil 
analisa dapat digunakan oleh pimpinan koperasi untuk perbaikan penyusunan rencana yang akan dilakukan di waktu yang akan datang. Laporan keuangan dibuat untuk menyediakan informasi yang menyakut posisi keuangan hal ini bermanfaat bagi sejumlah besar pemakai dalam pengambilan keputusan ekonomi. Laporan keuangan merupakan salah satu informasi yang sangat penting dalam menilai perkembangan suatu usaha, dapat juga digunakan untuk menilai prestasi yang telah di capai baik itu pada masa lampau, sekarang dan rencana pada waktu yang akan datang.

Laporan keuangan sangat diperlukan untuk mengukur sejauh mana hasil usaha dan perkembangan usaha dari waktu ke waktu dalam mencapai tujuannya, "Ukuran yang sering dipakai dalam mengukur kinerja keuangan pada koperasi dapat diukur berdasarkan Peraturan Pengawasan Kementerian Koperasi Dan Usaha Kecil Menengah (UKM) Republik Indonesia Nomor: 06/Per/Dep.6/IV/2016 mengenai pedoman penilaian Kesehatan Koperasi Simpan Pinjam dan Unit Simpan Pinjam".

Menurut Kementerian Koperasi Republik Indonesia (2016:1-2) "Salah satu cara untuk menilai kinerja keuangan pada koperasi dengan menggunakan 7 standar penilaian aspek dan komponen pada laporan keuangan koperasi. Yang terdiri dari, Aspek Permodalan, Aspek Kualitas Aktiva Produktif, Aspek Manajemen, Aspek Efisiensi, Aspek Likuiditas, Aspek Kemandirian dan Pertumbuhan, dan Aspek Jati diri Koperasi”. Berdasarkan standar tersebut dapat dilakukannya evaluasi atau perbaikan untuk mencegah semakin memburuknya kondisi atau kesehatan koperasi. Untuk melihat sehat tidaknya suatu koperasi tersebut tidak hanya dapat dinilai baik dari segi keadaan fisiknya saja, tetapi juga dapat dilihat dari kemampuan koperasi dalam menghasilkan laba dan mensejahterakan anggota nya serta masyarakat pada umumnya.

Dengan mengetahui tingkat standar penilaian tersebut akan dapat diketahui keadaan yang sesungguhnya. Analisis rasio keuangan merupakan sebuah cara menganalisis dengan menggunakan perhitungan atas data laporan keuangan yang ditunjukan. Dengan kita menggunakan perhitungan atau rumus rasio tersebut kita dapat mengetahui kinerja keuangan atau prestasi suatu koperasi dalam rentang waktu tertentu, apabila terjadi nya penurunan atau kenaikan di setiap tahunnya.

Berdasarkan hal tersebut maka dapat dipahami bahwa hubungan antara rasio keuangan dengan kinerja keuangan adalah dengan menggunakan rasio keuangan atau standar penilaian koperasi sehingga 
suatu koperasi dapat lebih mudah merencanakan dan mengatur segala kebutuhan untuk mengukur kekuatan dan kelemahan koperasi dalam mencapai dan meningkatkan yang di cita-citakan.

Berdasarkan hasil observasi sebelum penelitian dapat dilihat bahwa Koperasi Pegawai Republik Indonesia (KPRI) Bakti Guru Palembang merupakan salah satu koperasi yang bergerak dalam usaha simpan pinjam bagi anggotanya. Koperasi tersebut belum pernah melalukan penganalisisan terkhusus nya di bagian keuangan yang berpedoman pada SK pemerintah USP (Unit Simpan Pinjam) tahun 2016.Oleh karena itu, upaya untuk mengetahui adanya peningkatan atau penurunan pada koperasi khusus nya di bagian keuangan sebaiknya di adakan ALK memakai standar penilaian yang berdasarkan pada pedoman penilaian kesehatan koperasi simpan pinjam Kementerian Koperasi dan UKM Republik Indonesia Peraturan Nomor: 06/Per/Dep.6/IV/2016. Sehingga dapat mempermudah pimpinan dalam mengambil keputusan. Serta dapat memastikan bahwa sejauh mana efektifitas operasi usaha koperasi dalam mencapai laba maka secara periodik dilakukan analisis keuangan untuk menilai kinerja keuangan.

Berdasarkan latar belakang di atas, maka penulis tertarik untuk meneliti dan mengakat judul mengenai : "Analisis Rasio Keuangan Untuk Menilai Kinerja Keuangan Pada Koperasi Pegawai Republik Indonesia (Kpri) Bakti Guru Palembang”.

\section{METODOLOGI PENELITIAN}

Menurut Sugiyono (2012:2) "Metode penelitian pada dasarnya merupakan cara ilmiah untuk mendapatkan data dengan tujuan dan kegunaan tertentu".

"Metode penelitian merupakan pengumpulan data dengan cara di teliti dengan tujuan untuk peneltian yang data nya digunakan oleh peneliti" (Arikunto 2010:203)

Metode penelitian yang digunakan dalam penelitian ini ialah menggunakan metode Kuantitatif Deskriptif. Karena Menurut Sugiyono (2018:13) "Metode kuantitatif merupakan data yang berbentuk angka-angka". Dan Menurut Nazir (2014:43) "Metode deskriptif adalah metode yang meneliti suatu sekelompok manusia, suatu objek, suatu kondisi, suatu sistem pemikiran, ataupun suatu kelas peristiwa pada masa sekarang". Tujuan dari penelitian deskriptif ini adalah untuk mendeskripsikan dan menjelaskan yang menjadi ojek dari penelitian yang berupa laporan keuangan yang berbentuk angkaangka.

HASIL DAN PEMBAHASAN

Hasil Penelitian

Deskripsi pelaksanaan penelitian 
pertama kali di namakan Koperasi Pegawai Negeri (KPN) Bakti Guru Palembang, bertempat di SD Negeri No.148 Kelurahan bukti sangkal kecamatan ilir timur II kota madya Palembang. Berdiri sesuai pembentukan tanggal 11 April 1981 kemudian mengusulkan badan hukum tahun 1985 dan di sahkan pada 09 Desember 1986 badan hukum No.002669/BH/XX/1986. Pada tahun 1998 perubahan di lakukan yakni, nama Koperasi Pegawai Negeri (KPN) berubah menjadi Koperasi Pegawai Republik Indonesia (KPRI) yang bergerak dalam usaha simpan pinjam, dengan badan hukum baru yaitu: Akta perubahan

No. 002669a/BH/VI/1986, tanggal 25 Mei 1998.

\section{Aspek permodalan"}

\section{A. "Rasio Modal Sendiri Terhadap Total Aset"}

Rasio Modal Sendiri Terhadap Total Asset $=\frac{\text { Modal Sendiri }}{\text { Total Asset }}$ X 100\%

Tahun $2016=\frac{\text { Rp. 3.527.829.013,72 }}{\text { Rp. 6.566.636.575,96 }} \times 100 \%=53,72 \%$

Tahun $2017=\frac{\text { Rp. } 4.028 .717 .490,16}{\text { Rp. } 6.539 .273 .147,65} \times 100 \%=61,60 \%$

Tahun $2018=\frac{\text { Rp. } 4 \cdot 359 \cdot 321 \cdot 120,66}{\text { Rp. 6.575.074.549,62 }} \times 100 \%=66,30 \%$

Tabel 1. "Penyetoran Rasio Modal Sendiri Terhadap Total Asset"

\begin{tabular}{|c|c|c|c|c|}
\hline "Tahun" & $\begin{array}{c}\text { "Rasio Modal } \\
\text { (\%)" }\end{array}$ & "Nilai" & $\begin{array}{c}\text { "Bobot } \\
\text { (\%)" }\end{array}$ & "Skor" \\
\hline 2016 & $53,72 \%$ & 100 & 6 & 6,00 \\
\hline 2017 & $61,60 \%$ & 50 & 6 & 3.00 \\
\hline 2018 & $66,30 \%$ & 50 & 6 & 3.00 \\
\hline
\end{tabular}

Sumber : Data hasil penelitian tahun 2019 berdasarkan Peraturan Menteri Negara dan UKM Republik Indonesia Nomor: 06/Per/Dep.6/IV/2016

\section{B. "Rasio Modal Sendiri Terhadap Pinjaman Diberikan Yang Berisiko"}

Rasio Modal Sendiri Terhadap Pinjaman Diberikan Yang Berisiko = Modal Sendiri

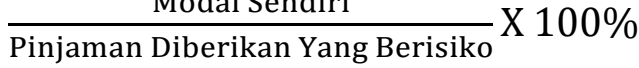

Tahun $2016=\frac{\text { Rp. 3.527.829.013,72 }}{\text { Rp. } 0} \times 100 \%=\infty$ (Tak terhingga)

Tahun $2017=\frac{\text { Rp. } 4.028 .717 .490,16}{\text { Rp. } 0} \times 100 \%=\infty$ (Tak terhingga)

Tahun $2018=\frac{\text { Rp. } 4 \cdot 359 \cdot 321 \cdot 120,66}{\text { Rp. } 0} \times 100 \%=\infty$ (Tak terhingga $)$ 
Tabel 2. "Penyetoran Rasio Modal Sendiri Terhadap Pinjaman diberikan yang Berisiko"

\begin{tabular}{|c|c|c|c|c|}
\hline $\begin{array}{c}\text { "Tahun } \\
"\end{array}$ & "Rasio Modal (\%)" & "Nilai" & $\begin{array}{c}\text { "Bobot } \\
\text { (\%)" }\end{array}$ & "Skor" \\
\hline 2016 & $\infty$ (Tak terhingga) & 100 & 6 & 6,0 \\
\hline 2017 & $\infty$ (Tak terhingga) & 100 & 6 & 6,0 \\
\hline 2018 & $\infty$ (Tak terhingga) & 100 & 6 & 6,0 \\
\hline
\end{tabular}

Sumber: Data hasil penelitian tahun 2019 berdasarkan Peraturan Menteri Negara dan UKM Republik Indonesia Nomor: 06/Per/Dep.6/IV/2016

\section{C. "Rasio Kecukupan Modal Sendiri"}

Rasio Kecukupan Modal Sendiri $=\frac{\text { Modal Sendiri Tertimbang }}{\text { ATMR }}$ X 100\%

Tahun $2016=\frac{\text { Rp. } 3.281 .964 .937,07}{\text { Rp. } 6.820 .351 .529,05} \times 100 \%=48,12 \%$

Tahun $2017=\frac{\text { Rp. } 3 \cdot 629.331 .617,00}{\text { Rp. } 6.096 .785 .730,02} \times 100 \%=59,52 \%$

Tahun $2018=\frac{\text { Rp. } 4.221 .864 .363,03}{\text { Rp. 5.643.966.376,07 }} \times 100 \%=74,80 \%$

Tabel 3. "Penyekoran Rasio Kecukupan Modal Sendiri"

\begin{tabular}{|c|c|c|c|c|}
\hline “Tahun" & "Rasio Modal (\%)" & "Nilai" & $\begin{array}{c}\text { "Bobot } \\
\text { (\%)" }\end{array}$ & "Skor" \\
\hline 2016 & $48,12 \%$ & 50 & 3 & 3.00 \\
\hline 2017 & $59,52 \%$ & 50 & 3 & 3.00 \\
\hline 2018 & $74,80 \%$ & 75 & 3 & 3.00 \\
\hline
\end{tabular}

Sumber : Data hasil penelitian tahun 2019 berdasarkan Peraturan Menteri Negara dan UKM Republik Indonesia Nomor: 06/Per/Dep.6/IV/2016

\section{2. “Aspek Kualitas Aktiva Produktif"}

\section{A. "Rasio Volume Pinjaman Pada Anggota Terhadap Volume Pinjaman} Diberikan"

Rasio Volume Pinjaman Pada Anggota Terhadap Volume Pinjaman

Diberikan $=\frac{\text { Volume Pinjaman Pada Anggota }}{\text { Volume Pinjaman }} \times 100 \%$

Tahun $2016=\frac{\text { Rp. } 5 \cdot 315.523 .119,39}{\text { Rp. 5.315.523.119,39 }} \times 100 \%=100 \%$

Tahun $2017=\frac{\text { Rp. } 5 \cdot 698.053 .870,38}{\text { Rp. } 5.698 .053 .870,38} \times 100 \%=100 \%$

Tahun $2018=\frac{\text { Rp. } 5 \cdot 106.444 .333,49}{\text { Rp. } 5.106 .444 .333,49} \times 100 \%=100 \%$ 
Tabel 4. "Rasio Volume Pinjaman Pada Anggota Terhadap Volume Pinjaman Diberikan"

\begin{tabular}{|c|c|c|c|c|}
\hline “Tahun" & "Rasio Modal (\%)" & "Nilai" & $\begin{array}{c}\text { "Bobot } \\
\text { (\%)" }\end{array}$ & "Skor" \\
\hline 2016 & $100 \%$ & 10 & 10 & 10,00 \\
\hline 2017 & $100 \%$ & 10 & 10 & 10,00 \\
\hline 2018 & $100 \%$ & 10 & 10 & 10,00 \\
\hline
\end{tabular}

Sumber : Data hasil penelitian tahun 2019 berdasarkan Peraturan Menteri Negara dan UKM Republik Indonesia Nomor: 06/Per/Dep.6/IV/2016

B. "Rasio Risiko Pinjaman Bermasalah Terhadap Pinjaman Yang Diberikan"

Rasio Risiko Pinjaman Bermasalah Terhadap Pinjaman Yang Diberikan $=\frac{\text { Pinjaman Bermasalah }}{\text { Pinjaman Yang Diberikan }}$ X 100\%

Tahun $2016=\frac{\text { Rp. } 0}{\text { Rp. } 4.246 .070 .000,00} \times 100 \%=0 \%$

Tahun $2017=\frac{\text { Rp. } 0}{\text { Rp. 5.233.285.000,00 }} \times 100 \%=0 \%$

Tahun $2018=\frac{\text { Rp. } 0}{\text { Rp. } 3.672 .422 .758,00} \times 100 \%=0 \%$

Tabel 5. "Penyekoran Rasio Risiko Pinjaman Bermasalah Terhadap Pinjaman Diberikan"

\begin{tabular}{|c|c|c|c|c|}
\hline "Tahun" & $\begin{array}{c}\text { "Rasio Modal } \\
\text { (\%)" }\end{array}$ & "Nilai" & "Bobot (\%)" & “Skor" \\
\hline 2016 & $0 \%$ & 100 & 5 & 5,0 \\
\hline 2017 & $0 \%$ & 100 & 5 & 5,0 \\
\hline 2018 & $0 \%$ & 100 & 5 & 5,0 \\
\hline
\end{tabular}

Sumber : Data hasil penelitian tahun 2019 berdasarkan Peraturan Menteri Negara dan UKM Republik Indonesia Nomor: 06/Per/Dep.6/IV/2016

\section{C. "Rasio Cadangan Risiko Terhadap Pinjaman Bermasalah"}

Rasio Cadangan Risiko Terhadap Pinjaman Bermasalah

$$
=\frac{\text { Cadangan Risiko }}{\text { Pinjaman Bermasalah }} \text { X 100\% }
$$

Tahun $2016=\frac{\text { Rp. 835,073,675,22 }}{\text { Rp. } 0} \times 100 \%=\infty$ (Tak terhingga)

Tahun $2017=\frac{\text { Rp. } 1.002 .533 .349,21}{\text { Rp. } 0} \times 100 \%=\infty($ Tak terhingga $)$ 
Tahun $2018=\frac{\text { Rp. } 1.224 .715 .583,84}{\text { Rp. } 0} \times 100 \%=\infty$ (Tak terhingga $)$

Tabel 6. "Penyekoran Rasio Cadangan Risiko Terhadap Pinjaman Bermasalah"

\begin{tabular}{|c|c|c|c|c|}
\hline “Tahun" & "Rasio Modal (\%)" & "Nilai" & $\begin{array}{c}\text { "Bobot } \\
\text { (\%)" }\end{array}$ & “Skor" \\
\hline 2016 & $\infty$ (Tak terhingga) & 100 & 5 & 5,0 \\
\hline 2017 & $\infty$ (Tak terhingga) & 100 & 5 & 5,0 \\
\hline 2018 & $\infty$ (Tak terhingga) & 100 & 5 & 5,0 \\
\hline
\end{tabular}

Sumber : Data hasil penelitian tahun 2019 berdasarkan Peraturan Menteri Negara dan UKM Republik Indonesia Nomor: 06/Per/Dep.6/IV/2016

D. "Rasio Pinjaman Yang Berisiko Terhadap Pinjaman Yang Diberikan"

Rasio Pinjaman Yang Berisiko Terhadap Pinjaman Yang Diberikan $=\frac{\text { Pinjaman Yang Berisiko }}{\text { Pinjaman Yang Diberikan }}$ 100\%

Tahun $2016=\frac{\text { Rp. } 0}{\text { Rp. } 4.246 .070 .000,00} \times 100 \%=0 \%$

Tahun $2017=\frac{\text { Rp. } 0}{\text { Rp. 5.233.285.000,00 }} \times 100 \%=0 \%$

Tahun $2018=\frac{\text { Rp. } 0}{\text { Rp. } 3.672 .422 .758,00} \times 100 \%=0 \%$

Tabel 7. "Penyekoran Rasio Pinjaman Yang Berisiko Terhadap Pnjaman Yang Diberikan"

\begin{tabular}{|c|c|c|c|c|}
\hline “Tahun" & $\begin{array}{c}\text { "Rasio Modal } \\
\text { (\%)" }\end{array}$ & "Nilai" & "Bobot (\%)" & "Skor" \\
\hline 2016 & $0 \%$ & 100 & 5 & 5,00 \\
\hline 2017 & $0 \%$ & 100 & 5 & 5,00 \\
\hline 2018 & $0 \%$ & 100 & 5 & 5,00 \\
\hline
\end{tabular}

Sumber : Data hasil penelitian tahun 2019 berdasarkan Peraturan Menteri Negara dan UKM Republik Indonesia Nomor: 06/Per/Dep.6/IV/2016

3. "Aspek Efisiensi"

A. "Rasio Beban Operasi Anggota Terhadap Partisipasi Bruto"

Rasio Beban Operasi Anggota Terhadap Partisipasi Bruto

$=\frac{\text { Beban Operasi Anggota }}{\text { Partisipasi Bruto }}$ X 100\% 
Tahun $2016=\frac{\text { Rp. } 186.412 .000,00}{\text { Rp. } 846.252 .849,06} \times 100 \%=22,02 \%$

Tahun $2017=\frac{\text { Rp. } 187.883 .000,00}{\text { Rp. } 953.891 \cdot 659,25} \times 100 \%=19,69 \%$

Tahun $2018=\frac{\text { Rp. } 252.758 .764,00}{\text { Rp. } 1.012 .472 .966,80} \times 100 \%=24,96 \%$

Tabel 8. "Penyekoran Rasio Beban Operasi Anggota Terhadap Partisipasi Bruto"

\begin{tabular}{|c|c|c|c|c|}
\hline "Tahun" & $\begin{array}{c}\text { "Rasio } \\
\text { Modal (\%)" }\end{array}$ & "Nilai" & $\begin{array}{c}\text { "Bobot } \\
\text { (\%)" }\end{array}$ & "Skor" \\
\hline 2016 & $22,02 \%$ & 100 & 4 & 4 \\
\hline 2017 & $19,69 \%$ & 100 & 4 & 4 \\
\hline 2018 & $24,96 \%$ & 100 & 4 & 4 \\
\hline
\end{tabular}

Sumber : Data hasil penelitian tahun 2019 berdasarkan Peraturan Menteri Negara dan UKM Republik Indonesia Nomor: 06/Per/Dep.6/IV/2016

\section{B. "Rasio Beban Usaha Terhadap SHU Kotor"}

Rasio Beban Usaha Terhadap SHU Kotor $=\frac{\text { Beban Usaha }}{\text { SHU Kotor }}$ X 100\%

Tahun $2016=\frac{\text { Rp. } 446.690 .125,00}{\text { Rp. } 410.668 .138,50} \times 100 \%=108,77 \%$

Tahun $2017=\frac{\text { Rp. } 415.416 .502,00}{\text { Rp. } 521.538 .540,95} \times 100 \%=79,65 \%$

Tahun $2018=\frac{\text { Rp. } 528.482 .679,00}{\text { Rp. } 494.818 .936,82} \times 100 \%=106,80 \%$

Tabel 9. "Penyekoran Rasio Beban Usaha Terhadap SHU Kotor"

\begin{tabular}{|c|c|c|c|c|}
\hline “Tahun" & $\begin{array}{c}\text { "Rasio Modal } \\
\text { (\%)" }\end{array}$ & “Nilai" & $\begin{array}{c}\text { "Bobot } \\
\text { (\%)" }\end{array}$ & "Skor" \\
\hline 2016 & $108,77 \%$ & 25 & 4 & 1 \\
\hline 2017 & $79,65 \%$ & 50 & 4 & 2 \\
\hline 2018 & $106,80 \%$ & 25 & 4 & 1 \\
\hline
\end{tabular}

Sumber : Data hasil penelitian tahun 2019 berdasarkan Peraturan Menteri Negara dan UKM Republik Indonesia Nomor: 06/Per/Dep.6/IV/2016

\section{C. "Rasio Efisiensi Pelayanan"}

Rasio Efisiensi Pelayanan $=\frac{\text { Biaya Karyawan }}{\text { Volume Pinjaman }}$ X 100\%

Tahun $2016=\frac{\text { Rp. } \quad 179.100 .000,00}{\text { Rp. } 5.315 \cdot 532.119,39} \times 100 \%=3,36 \%$ 
Tahun $2017=\frac{\text { Rp. } \quad 180.600 .000,00}{\text { Rp. } 5.698 .053 .870,38} \times 100 \%=3,16 \%$
Tahun $2018=\frac{\text { Rp. } 212.250 .000,00}{\text { Rp. 5.106.444.333,49 }} \times 100 \%=4,15 \%$

Tabel 10. "Penyekoran Rasio Efesiensi Pelayanan"

\begin{tabular}{|c|c|c|c|c|}
\hline "Tahun" & $\begin{array}{c}\text { "Rasio Modal } \\
\text { (\%)" }\end{array}$ & "Nilai" & $\begin{array}{c}\text { "Bobot } \\
\text { (\%)" }\end{array}$ & "Skor" \\
\hline 2016 & $3,36 \%$ & 100 & 2 & 2,0 \\
\hline 2017 & $3,16 \%$ & 100 & 2 & 2,0 \\
\hline 2018 & $4,15 \%$ & 100 & 2 & 2,0 \\
\hline
\end{tabular}

Sumber : Data hasil penelitian tahun 2019 berdasarkan Peraturan Menteri Negara dan UKM Republik Indonesia Nomor: 06/Per/Dep.6/IV/2016

\section{4. "Aspek Likuiditas"}

\section{A. "Rasio Kas dan Bank Terhadap Kewajiban Lancar"}

Rasio Kas dan Bank Terhadap Kewajiban Lancar $=\frac{\text { Kas }+ \text { Bank }}{\text { Kewajiban Lancar }}$ X 100\%

Tahun $2016=\frac{\text { Rp. } 50.134 .867,00+\text { Rp. } 530.303 .804,57}{\text { Rp. 3.038.807.562,24 }} \times 100 \%=19,10 \%$

Tahun $2017=\frac{\text { Rp. } 53 \cdot 414.978,00+\text { Rp. } 257.879 .514,27}{\text { Rp. } 2.510 .555 .657,49} \times 100 \%=12,39 \%$

Tahun $2018=\frac{\text { Rp. } \quad 2.285 \cdot 358,00+\text { Rp. } 933 \cdot 170.073,13}{\text { Rp. } 2 \cdot 215.753 .428,96} \times 100 \%=42,21 \%$

Tabel 11. "Penyekoran Rasio Kas dan Bank Terhadap Kewajiban Lancar"

\begin{tabular}{|c|c|c|c|c|}
\hline "Tahun" & $\begin{array}{c}\text { "Rasio Modal } \\
\text { (\%)" }\end{array}$ & "Nilai" & "Bobot (\%)" & "Skor" \\
\hline 2016 & $19,10 \%$ & 50 & 10 & 5 \\
\hline 2017 & $12,39 \%$ & 100 & 10 & 10 \\
\hline 2018 & $42,21 \%$ & 25 & 10 & 2,5 \\
\hline
\end{tabular}

Sumber : Data hasil penelitian tahun 2019 berdasarkan Peraturan Menteri Negara dan UKM Republik Indonesia Nomor: 06/Per/Dep.6/IV/2016

\section{B. "Rasio Pinjaman Yang Diberikan Terhadap Dana Yang Diterima"}

Rasio Pinjaman Yang Diberikan Terhadap Dana Yang Diterima $=$ $\frac{\text { Pinjaman Yang Diberikan }}{\text { Dana Yang Diterima }}$ X 100\%

Tahun $2016=\frac{\text { Rp. } 4.246 .070 .000,00}{\text { Rp. } 4.850 .090 .053,00} \times 100 \%=87,54 \%$

Tahun $2017=\frac{\text { Rp. } 5.233 .285 .000,00}{\text { Rp. } 4.850 .754 .249,01} \times 100 \%=107,88 \%$

Tahun $2018=\frac{\text { Rp. } 3 \cdot 672.422 .758,00}{\text { Rp. } 4.278 .179 .852,14} \times 100 \%=85,84 \%$ 
Tabel 12. "Penyekoran Rasio Pinjaman Yang Diberikan Terhadap Dana Yang Diterima"

\begin{tabular}{|c|c|c|c|c|}
\hline “Tahun" & "Rasio Modal (\%)" & "Nilai" & $\begin{array}{c}\text { "Bobot } \\
\text { (\%)" }\end{array}$ & "Skor" \\
\hline 2016 & $87,54 \%$ & 100 & 5 & 5 \\
\hline 2017 & $107,88 \%$ & 100 & 5 & 5 \\
\hline 2018 & $85,84 \%$ & 100 & 5 & 5 \\
\hline
\end{tabular}

Sumber : Data hasil penelitian tahun 2019 berdasarkan Peraturan Menteri Negara dan UKM Republik Indonesia Nomor: 06/Per/Dep.6/IV/2016

Tabel 13. "Penyekoran Akhir Koperasi Pegawai Republik Indonesia (KPRI) Bakti Guru Palembang Tahun 2016-2018"

\begin{tabular}{|c|c|c|c|c|}
\hline No & Aspek Yang Dinilai & $\begin{array}{l}\text { Skor } \\
2016\end{array}$ & $\begin{array}{l}\text { Skor } \\
2017\end{array}$ & $\begin{array}{l}\text { Skor } \\
2018\end{array}$ \\
\hline \multirow[t]{5}{*}{1.} & Aspek Permodalan & & & \\
\hline & a. Rasio Modal Sendiri Terhadap Total Aset & 6 & 3 & 3 \\
\hline & $\begin{array}{l}\text { b. Rasio Modal Sendiri Terhadap Pinjaman } \\
\text { Diberikan Yang Berisiko }\end{array}$ & 6 & 6 & 6 \\
\hline & c. Rasio Kecukupan Modal Sendiri & 3 & 3 & 3 \\
\hline & Jumlah Skor Permodalan & 15 & 12 & 12 \\
\hline \multirow[t]{6}{*}{2.} & Aspek Kualitas Aktiva Produktif & & & \\
\hline & $\begin{array}{l}\text { a. Rasio Volume Pinjaman Pada Anggota } \\
\text { Terhadap Volume Pinjaman Diberikan }\end{array}$ & 10 & 10 & 10 \\
\hline & $\begin{array}{l}\text { b. Rasio Risiko Pinjaman Bermasalah Terhadap } \\
\text { Pinjaman Yang Diberikan }\end{array}$ & 5 & 5 & 5 \\
\hline & $\begin{array}{l}\text { c. Rasio Cadangan Risiko Terhadap Pinjaman } \\
\text { Bermasalah }\end{array}$ & 5 & 5 & 5 \\
\hline & $\begin{array}{l}\text { d. Rasio Pinjaman Yang Berisiko Terhadap } \\
\text { Pinjaman Yang Diberikan }\end{array}$ & 5 & 5 & 5 \\
\hline & Jumlah Skor Kualitas Aktiva Produktif & 25 & 25 & 25 \\
\hline \multirow[t]{5}{*}{3.} & Aspek Efesiensi & & & \\
\hline & $\begin{array}{l}\text { a. Rasio Beban Operasi Anggota Terhadap } \\
\text { Partisipasi Bruto }\end{array}$ & 4 & 4 & 4 \\
\hline & b. Rasio Beban Usaha Terhadap SHU Kotor & 1 & 2 & 1 \\
\hline & c. Rasio Efisiensi Pelayanan & 2 & 2 & 2 \\
\hline & Jumlah Skor Efisiensi & 7 & 8 & 7 \\
\hline \multirow[t]{4}{*}{4.} & Aspek Likuiditas & & & \\
\hline & a. Rasio Kas & 5 & 10 & 2,5 \\
\hline & $\begin{array}{l}\text { b. Rasio Pinjaman Yang Diberikan Terhadap Dana } \\
\text { Yang Diterima }\end{array}$ & 5 & 5 & 5 \\
\hline & Jumlah Skor Likuiditas & 10 & 15 & $\mathbf{7 , 5}$ \\
\hline \multicolumn{2}{|c|}{ TOTAL SKOR } & 57 & 60 & $\mathbf{5 1 , 5}$ \\
\hline
\end{tabular}

Sumber: Diolah dari hasil penelitian. 
Tabel 14. "Berikut penjelasan perhitungan predikatnya penilaian aspek permodalan"

\begin{tabular}{|l|c|c|c|}
\hline \multicolumn{3}{|c|}{} & \multicolumn{2}{l|}{$\begin{array}{l}\text { Total keseluruhan Skor Permodalan } \\
15\end{array}$} \\
\multicolumn{1}{|c|}{ Skor } & Predikat & Skor & Predikat \\
\hline $80.00 \leq \mathrm{x} \leq 100$ & Sehat & $12 \leq \mathrm{x} \leq 15$ & normal \\
\hline $\begin{array}{l}66.00 \leq \mathrm{x}< \\
80.00\end{array}$ & Cukup Sehat & $9,9 \leq \mathrm{x}<12$ & Cukup normal \\
\hline $\begin{array}{l}51.00 \leq \mathrm{x}< \\
66.00\end{array}$ & Dalam Pengawasan & $7,65 \leq \mathrm{x}<9,9$ & Dalam Pengamatan \\
\hline$<51$ & $\begin{array}{c}\text { Dalam Pengawasan } \\
\text { Khusus }\end{array}$ & $<7,65$ & $\begin{array}{c}\text { Dalam Pengamatan } \\
\text { Khusus }\end{array}$ \\
\hline $\begin{array}{l}\text { Perhitungan: } \\
\frac{80}{100} \times 15=12\end{array}$ & & & \\
$\frac{66}{100} \times 15=9,9$ & 51 \\
$\frac{5}{100} \times 15=7,65$ & \multicolumn{4}{|l}{} \\
\hline
\end{tabular}

Sumber: Peraturan Menteri Negara USP (Unit Simpan Pinjam)Tahun 2016

Tabel 15. "Berikut penjelasan perhitungan predikatnya penilaian aspek kualitas aktiva produktif"'

\begin{tabular}{|l|c|l|c|}
\hline \multicolumn{3}{|c|}{} & \multicolumn{2}{c|}{$\begin{array}{c}\text { Total keseluruhan Skor Permodalan } 25 \\
\text { Total Keseluruhan Skor Aspek 100 }\end{array}$} \\
\hline \multicolumn{1}{|c|}{ Skor } & Predikat & Skor & Predikat \\
\hline $60.00 \leq \mathrm{x} \leq 100$ & Sehat & $20 \leq \mathrm{x} \leq 25$ & normal \\
\hline $51.00 \leq \mathrm{x}<66.00$ & $\begin{array}{c}\text { Dalam } \\
\text { Pengawasan }\end{array}$ & $12,75 \leq \mathrm{x}<16,5$ & Dakup normal \\
\hline$<51$ & $\begin{array}{c}\text { Dalam } \\
\text { Pengawasan } \\
\text { Khusus }\end{array}$ & $<12,75$ & Dalam Pengamatan \\
& & & Khusus \\
\hline Perhitungan: & & & \\
$\frac{80}{100} \times 25=20$ & & & \\
$\frac{66}{100} \times 25=16,5$ & & & \\
$\frac{51}{100} \times 25=12,75$ & & & \\
\hline
\end{tabular}

Sumber: Peraturan Menteri Negara USP (Unit Simpan Pinjam)Tahun 2016 
Tabel 16 "Berikut penjelasan perhitungan predikatnya penilaian aspek efisiensi"

\begin{tabular}{|c|c|c|c|}
\hline & \multicolumn{2}{|c|}{$\begin{array}{l}\text { Total keseluruhan Skor Permodalan } \\
10 \\
\text { Total Keseluruhan Skor Aspek } 100\end{array}$} \\
\hline Skor & Predikat & Skor & Predikat \\
\hline $80.00 \leq x \leq 100$ & Sehat & $8 \leq x \leq 10$ & normal \\
\hline $66.00 \leq x<80.00$ & Cukup Sehat & $6,6 \leq x<8$ & Cukup normal \\
\hline $51.00 \leq x<66.00$ & Dalam Pengawasan & $5,1 \leq x<6,6$ & Dalam Pengamatan \\
\hline$<51$ & $\begin{array}{c}\text { Dalam Pengawasan } \\
\text { Khusus }\end{array}$ & $<5,1$ & $\begin{array}{c}\text { Dalam Pengamatan } \\
\text { Khusus }\end{array}$ \\
\hline \multicolumn{4}{|l|}{ Perhitungan: } \\
\hline $80 \times 10=8$ & \\
\hline \\
\hline \multicolumn{4}{|l|}{$\frac{100}{10} \times 10=6,6$} \\
\hline$\frac{51}{100} \times 10=5,1$ & & & \\
\hline
\end{tabular}

Sumber: Peraturan Menteri Negara USP (Unit Simpan Pinjam)Tahun 2016

Tabel 17. "Berikut penjelasan perhitungan predikatnya penilaian aspek likuiditas"

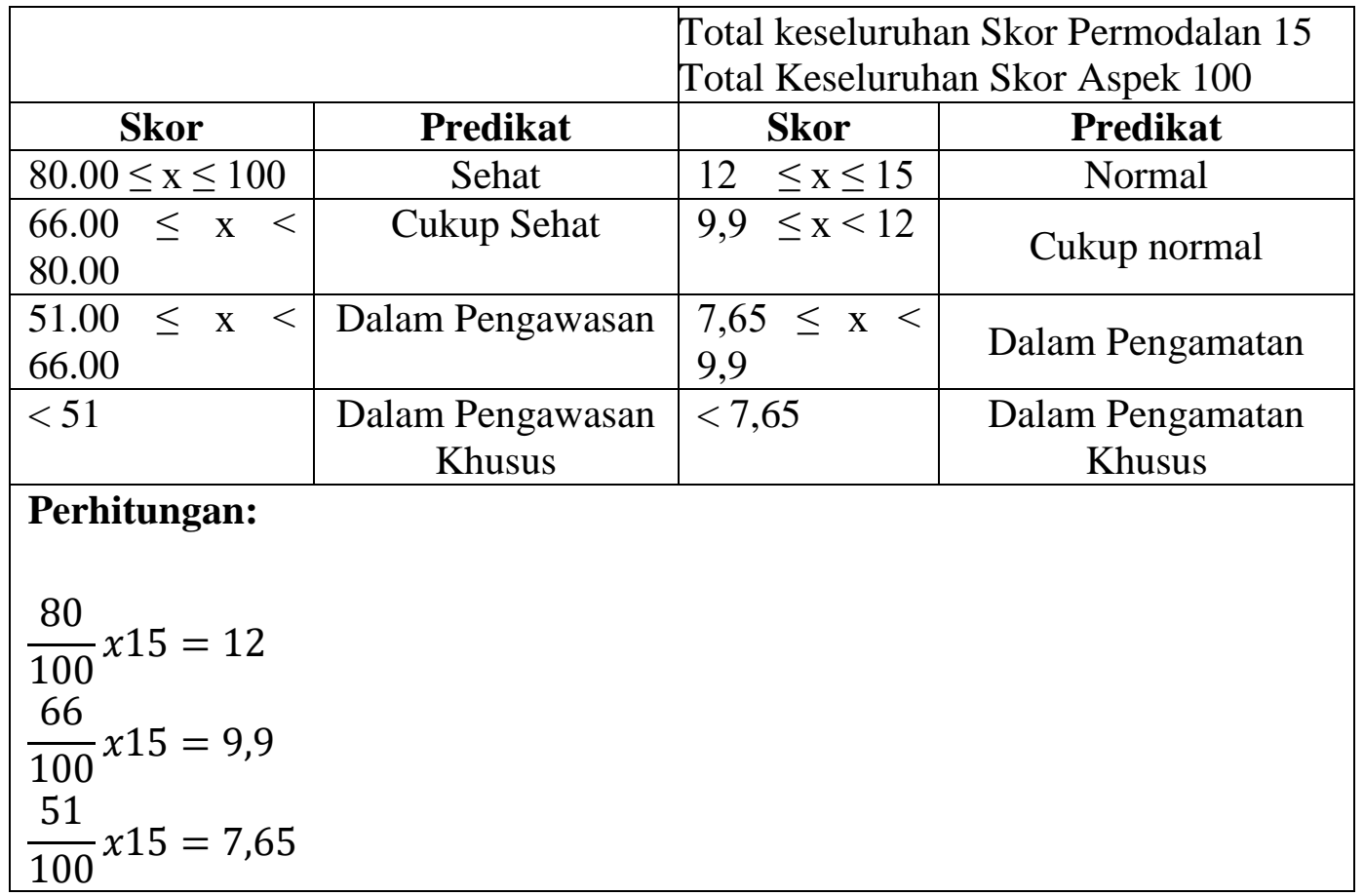

Sumber: Peraturan Menteri Negara USP (Unit Simpan Pinjam) Tahun 2016 
Pembahasan

Penilain Apek Permodalan KSP (Koperasi Simpan Pinjam) Bakti Guru Palembang Tahun 2016-2018

Berdasarkan hasil analisis yang telah di lakukan, menunjukkan bahwa pada aspek permodalan KSP (Koperasi Simpan Pinjam) Bakti Guru Palembang tahun 2016 diperoleh skor 15, sedangkan tahun 2017 dan 2018 diperoleh jumlah skor akhir yang sama yakni 12.Dimana skor predikat kesehatan maksimal nya, untuk aspek peromadalan berkisaran 12-15 (Berdasarkan tolak ukur pada tabel 3.3). Artinya Koperasi Simpan Pinjam Bakti Guru Palembang memperoleh predikat sehat selama tiga tahun terakhir dari 2016-2018. Skor tersebut diwakili oleh rasio modal sendiri terhadap total aset, rasio modal sendiri terhadap pinjaman diberikan yang berisiko, dan rasio kecukupan modal sendiri.

\section{Penilaian Apek Kualitas Aktiva Produktif KSP (Koperasi Simpan Pinjam) Bakti Guru Palembang Tahun 2016-2018}

Berdasarkan hasil analisis yang telah di lakukan, menunjukkan bahwa pada aspek kualitas aktiva produktif KSP (Koperasi Simpan Pinjam) Bakti Guru Palembang tahun 2016-2018 memperoleh jumlah skor akhir yang sama yakni 25 selama tiga tahun berturut. Dimana skor predikat kesehatan maksimal nya, untuk aspek kualitas aktiva produktif berkisaran 20-25 (Berdasarkan tolak ukur pada tabel 3.4). Artinya Koperasi Simpan Pinjam Bakti Guru Palembang memperoleh predikat sehat selama tiga tahun terakhir dari 2016-2018. Skor tersebut diwakili oleh rasio volume pinjaman pada anggota terhadap volume pinjaman diberikan, rasio risiko pinjaman bermasalah terhadap pinjaman yang diberikan, rasio cadangan risiko terhadap pinjaman bermasalah, dan rasio pinjaman yang berisiko terhadap pinjaman yang diberikan.

Penilaian Apek Efisiensi KSP (Koperasi Simpan Pinjam) Bakti Guru Palembang Tahun 2016-2018

Berdasarkan hasil analisis yang telah di lakukan, menunjukkan bahwa pada aspek efisiensi KSP (Koperasi Simpan Pinjam) Bakti Guru Palembang tahun 2016 dan 2018 diperoleh skor 7, sedangkan tahun 2017 diperoleh skor 8.Dimana skor maksimal nya, untuk predikat kesehatan aspek efisiensi berkisaran 8-10 (Berdasarkan tolak ukur pada tabel 3.5). Artinya Koperasi Simpan Pinjam Bakti Guru Palembang memperoleh predikat cukup sehat pada tahun 2016 dan 2018. Sedangkan di tahun 2017 memperoleh predikat sehat. Skor tersebut diwakili oleh rasio modal sendiri terhadap total aset, rasio modal sendiri terhadap pinjaman diberikan yang berisiko, dan rasio kecukupan modal sendiri. 
Penilaian Apek Likuiditas KSP (Koperasi Simpan Pinjam) Bakti Guru Palembang Tahun 2016-2018

Berdasarkan hasil analisis yang telah di lakukan, menunjukkan bahwa pada aspek likuiditas KSP (Koperasi Simpan Pinjam) Bakti Guru Palembang tahun 2016 diperoleh skor 10 , sedangkan tahun 2017 memperoleh skor 15, dan tahun 2018 diperoleh skor 7,5. Dimana skor maksimalpredikat aspek likuiditas berkisaran 12-15 (Berdasarkan tolak ukur pada tabel 3.6). Artinya Koperasi Simpan Pinjam Bakti Guru Palembang memperoleh predikat cukup sehat pada tahun 2016, sedangkan di tahun 2017 mendapatkan predikat sehat, dan di tahun 2018 mendapatkan predikat dalam pengawasan khusus dengan. Skor tersebut diwakili oleh rasio modal sendiri terhadap total aset, rasio modal sendiri terhadap pinjaman diberikan yang berisiko, dan rasio kecukupan modal sendiri.

\section{Kinerja Keuangan Koperasi Pegawai Republik Indonesia (KPRI) Bakti Guru Palembang Tahun 2016-2018}

Berdasarkan total akhir perhitungan skor secara maka telah dapat kita ketahui kinerja keuangan koperasi selama tiga tahun ini, pada tahun 2016 perolehan skor akhir dari penilaian ke 4 aspek tersebut yakni 57 point, sedangkan pada tahun 2017 total akhir yang di dapat yakni 60 point, selisi 3 point dari tahun 2016 yang artinya mengalami kenaikan di tahun 2017. Sedangkan di tahun 2018 kembali mengalami penurunan yang drastis yakni dengan point 51,5 penurunan ini di akibatkan perolehan skor pada spek likuiditas di bagian rasio kas dari 10 menjadi 2,5. Maka dapat disimpulkan bahwa kinerja keuangan pada Koperasi Simpan Pinjam (USP) Bakti Guru Palembang sepanjang 3 tahun terakhir ini, yakni dari tahun 2016 sampai dengan 2018, menunjukkan bahwa kinerja keuangan koperasi mengalami naik turun di setiap tahunnya.

\section{KESIMPULAN DAN SARAN Kesimpulan}

Berdasarkan hasil analisis dan pembahasan yang telah di jelaskan pada bab sebelumnya, maka dapat di simpulkan jika di lihat dari perolehan skor akhir dari ke 4 aspek tersebut dari tahun 2016 sampai dengan tahun 2018 menunjukkan bahwa kinerja keuangan pada Koperasi Pegawai Republik Indonesia (KPRI) Bakti Guru Palembang mengalami naik turun di setiap tahunnya. Dimana tahun 2016 dan 2017 memperoleh predikat sehat, sedangkan di tahun 2018 memperoleh predikat dalam pengawasan khusus, hal tersebut di karenakan terjadinya penurunan pada aspek likuiditas di bagian rasio kas dari 10 menjadi 2,5 berikut penjabaran nya:

1. Di tahun 2016-2018 Untuk aspek permodalan pada KSP (Koperasi Simpan Pinjam) Bakti 
Guru Palembang di tahun memperoleh predikat sehat, dengan point akhir yang di dapat $15,12,12$.

2. Di tahun 2016-2018 Aspek kualitas aktiva produktif pada memperoleh dengan predikat sehat, dengan skor akhir 25.

3. Sedangkan untuk Aspek efisiensi di tahun 2016 dan 2018 memperoleh nilai yang sama yakni skor akhir yang di dapat 7 masuk dalam kategori cukup sehat, dan pada tahun 2017 skor akhir nya 8 masuk dalam kategori sehat.

4. Dan di Aspek likuidtas di tahun 2016 skor 8 yang di dapat dengan predikat kesehatan koperasicukup sehat, sedangkan di 2017 skor akhirnya 15 dengan kategori sehat, dan pada 2018 skor akhir 7,5 dengan predikat dalam pengawasan khusus.

\section{Saran}

Berdasarkan simpulan diatas, maka peneliti dapat memberikan saran sebagai berikut:

1. Bagi pihak koperasi, dari segi keseluruhan analisis telah di nyatakan sudah memdapatkan predikat sehat dari ke empat aspek masing-masing, untuk itu koperasi di harapkan dapat terus meningkatkan dan mempertahankan kinerja keuangan di tahun berikutnya.

2. Bagi peneliti selanjutnya, jika ingin mengetahui analisis rasio keuangan koperasi sesungguhnya, maka peneliti perlu menghitung keseluruhan aspek yang ada di Peraturan Menteri tahun 2016 agar mendapat gambaran kinerja kesehatan koperasi yang lebih jelas.

\section{DAFTAR PUSTAKA}

Afandi, Pandi. (2014). Analisis kinerja keuangan untuk mengukur kesehatan keuangan koperasi Ksu Bmt Arafat kecamatan Bancak kabupaten Semarang. Jurnal Among Makarti, Vol.7 No.13, (Online), (http://jurnal.stieama.ac.id/index .php/ama/article/view/93/76, diakses 11 April 2019)

Arikunto, Suharsimi. (2014). Prosuder Penelitian, Suatu Pendekatan Praktik. Jakarta: PT. Asdi Mahasatya.

Budiadi, Dwi. (2011). Pegukuran Kinerja keuangan koperasi dengan analisis rasio. Jurnal cahaya aktiva, Vol.01 No.01: Politeknik cahaya Surya Kendiri,(Online),(http://www.ca hayasurya.ac.id/jurnal/file/Hal\% 2029 34\%20Dwi\%20Budiadi.p df, diakses 11 April 2019)

Fahmi, Irham. (2012). Analisis Laporan Keuangan. Bandung: Alfabeta, CV.

Saraswati \& Handayani. (2013). Analisis laporan keuangan sebagai alat penilaian kinerja keuangan pada koperasi. Jurnal Administrasi Bisnis (JAB), Vol.6 No.2: $\quad$ Fakuktas Ilmu Administrasi, Universitas Brawijaya Malang, (Online),(http://administrasibisni s.studentjournal.ub.ac.id/index.p 
hp/jab/article/view/291/484,

diakses 11 April 2019)

Harahap, Syaftri Sofyan (2010). Analisis Kritis Atas Laporan Keuangan. Jakarta: PT RajaGrafindo Persada.

Jumingan. (2011). Analisis Laporan Keuangan. Jakarta: PT Bumi Aksara.

Kasmir. (2012). Analisis Laporan Keuangan. Jakarta: PT RajaGrafindo Persada.

Laely, Nur. (2015). Analisis laporan keuangan berdasarkan rasio likuiditas, Solvabilitas, dan Rentabilitas untuk menilai kinerja keuangan pada koperasi manunggal Universitas kadiri. Jurnal Kompilek, Vol.7 No.01 : Fakultas Ekonomi, Universitas Kendiri, (Online), (http://journal.stieken.ac.id/inde x.php/kompilek/article/view/153 , diakses 11 april 2019)

Ukkas \& Ningsi. (2014). Analisis Rentabilitas dan profitabilitas pada koperasi simpan pinjam balo'Toraja ksp. balo'Ta. Jurnal Manajemen, Vol.01

No.02,(Online),(https://docplaye r.info/37700482-Analisisrentabilitas-dan-profitabilitaspada-koperasi-simpan-pinjambalo-toraja-ksp-balo-ta-imranukkas1-wirda-ayu-ningsi2.html, diakses 11 April 2019)

Munir \& Indarti. (2011). Analisis Tingkat Kesehatan Koperasi Pada Koperasi Simpan Pinjam "Cendrawasih" Kecamatan Gubug. Jurnal Manajemen, Vol.03No.02,(Online),https://me dia.neliti.com/media/publication s/103236-ID-analisis-tingkatkesehatan-koperasi-pada.pdf, diakses 11 April 2019)
Nazir, Moh (2014). Metode Penelitian. Bogor: Ghalia Indonesia.

Peraturan Menteri Negara dan UKM Republik Indonesia Nomor 06/Per/Dep.6/IV/2016 tentang kriteria standar penilaian Kesehatan

Koperasi,(Online),(www.sumbar prov.go.id/images/1482118726Perdep06_2016_Penilaian_Kese hatan_KSP.pdf, diakses 11 April 2019)

Rudianto. (2010). Akuntansi Koperasi Edisi 2. Jakarta: Erlangga.

Samryn. (2014). Pengantar Akuntansi Mudah Membuat Jurnal Dengan Pendekatan Siklus Transaksi. Jakarta: PT RajaGrafindo Persada.

Subandi. (2017). Ekonomi Koperasi (Teori dan Praktik). Bandung: Alfabeta.

Sugiyono. (2018). Metode Penelitian Pendidikan Pendekatan Kuantitatif, Kualitatif dan $R \& D$. Bandung: Alfabeta. . (2012). Metode Penelitian Kuantitatif Kualitatif dan $R \& D$. Bandung: Alfabeta.

Universitas PGRI. (2018). Pedoman Penulisan Skripsi. Palembang: Fakultas Keguruan dan Ilmu pendidikan.

Yolanda, Zelvie. 2018. Analisis Penilaian Kesehatan Keuangan Koperasi Simpan Pinjam "Sejahtera" Di SMK Muhammadiyah 2 Palembang Tahun 2015-2017. Palembang: Fakultas Keguruan Ilmu Pendidikan Jurusan Akuntansi Universitas PGRI Palembang 